UDC 621.396

\title{
SURVEY OF SATELLITE TECHNOLOGIES APPLYING IN WIRELESS SENSOR NETWORKS
}

\author{
Olexander I. Lysenko, Sergey V. Kashuba, Valeriy I. Novikov, Tatyana O. Pryschepa \\ Telecommunications Department, Institute of Telecommunication Systems, \\ National Technical University of Ukraine "Kyiv Polytechnic Institute" \\ Kyiv, Ukraine
}

Background. There are scenarios of wireless sensor networks application, in which the use of terrestrial communication becomes unacceptable: a considerable distance between the sensor nodes, destruction of land lines during natural disasters and al. The alternative terrestrial communication to solve the problem to ensure the transmission of information from the sensor nodes can be the use of satellite communication channels. However, the use of satellite channels makes high demands on power transceivers, which imposes restrictions on the characteristics of the sensor nodes.

Objective. The aim of the paper is review of existing methods of application of satellite communication channels in wireless sensor networks.

Methods. Analysis of well-known publications on the use of satellite communication channels in wireless sensor networks, revealed specific scenarios in which the use of satellite channels can be an effective solution.

Results. It was found that, despite the additional complexity of the use of satellite communication channels in wireless sensor networks associated with the energy constraints of sensor nodes, satellite channels are able to provide the territorial flexibility for deployment of wireless sensor networks.

Conclusions. The use of satellite communications in wireless sensor networks has a number of unresolved problems. One example is problem of multiple access organization in satellite channel for high satellite channel utilization depends on payload traffic nature. A promising area of application of satellite communication channels in wireless sensor networks is a method of forming a data channel from a group of spaced sensor nodes with limited energy, which is based on the principles of phased arrays.

Keywords: wireless sensor networks; satellite channel.

\section{Introduction}

Many of economical, scientific and social spheres need instruments of information collection from large surfaces and its processing. There are some requirements of fast information transmission from collection points to data center in such applications. Another type of requirements is related to fast system deployment on target territory.

Fast development of microelectronic devices, wireless communications and digital computations allow manufacturing of cheap, low power consuming and multifunctional devices. They have small sizes and can transmit data through radio channel. In common, each device carries set of sensors, microprocessor and radio transceiver. Radio interface supports different network level protocols for interaction with other similar nodes. Such systems are called Wireless Sensor Networks (WSN) [1].

In particular, five WSN application scenarios are identified as significant [2]:

- monitoring and surveillance of remote areas;

- emergency communications;

- support for supervisory control and data acquisition (SCADA) systems;

- critical infrastructures (CIs) monitoring;

- environmental monitoring.

On the Fig. 1 generalized WSN scheme is depicted. Many sensor nodes collect and transmit data via wireless channels to one or several gateway (sink) nodes. Gateway node aggregates and sends data to data processing center.

In many cases such systems have critical limitation of terrestrial communication networks usage or other infrastructures access. Depends on WSN application scenario there are several cases when applying of terrestrial radio connection can be inefficient: huge distances among sensor nodes, demolishment of terrestrial communication infrastructure due to natural disasters. 


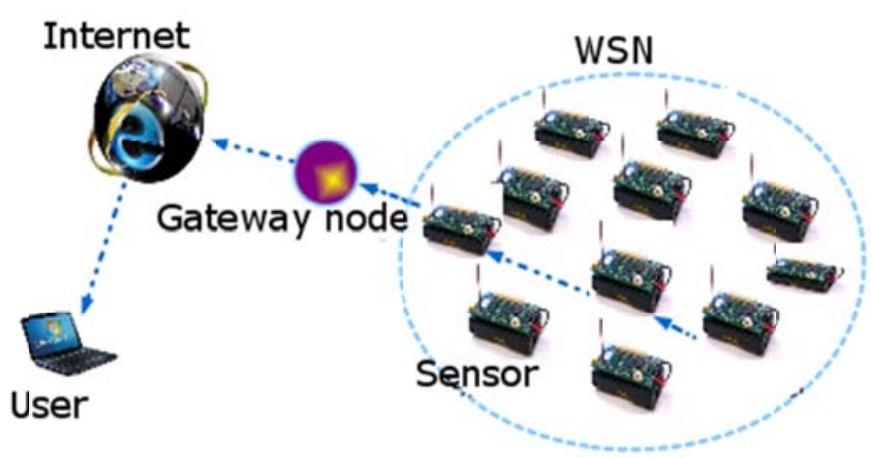

Fig. 1. Generalized WSN scheme

One alternative solution for communication problem between sensors and datacenter can be harnessing of satellite telecommunication systems (STS). In case of existing satellite channel it is possible to start system in shortest time comparing to time of other communication techniques deployment. The main drawback of satellite data transmission is high requirements of transceivers power budget. This issue is contrary to main features of typical WSN node design.

This article provides survey, which describes different usage methods of satellite channels in WSN systems design. We consider most typical examples and design features of satellite segment application in WSN. Additional power consumption which is possible with satellite link usage was taken into a count, so we propose short review of energy saving technics appropriate for considered WSNs.

\section{State of the Art technologies of WSN and Satellite systems}

The sensor nodes are the central element in a wireless sensor network (WSN). Typical node consists of four main subsystems: sensing, processing, communication and power supply [3].

Node carries one or several types of sensors. Work schedule of them and amount of generated data are very distinct: measuring of physical parameters once a day or continuous image transmission from camera. Main requirements for sensors are low power consumption and small size.

Processing subsystem controls node lifecycle and performs initial sensor data transformations (filtration, buffering, compression etc.). In case of hierarchical WSN structure some nodes are capable to aggregate raw data from other nodes to reduce total network load. Commonly this node part is represented as low power single-core microprocessor with limited memory and storage capacities.

Communication subsystem provides data transfer facilities from one node to others or/and base station. Depends on system requirements (max. throughput, power limitations, network topology) can be used one of wide adopted wireless technologies such as IEEE 802.15.4 (ZigBee, 6LoWPAN), IEEE 802.11 (Wi-Fi), IEEE 802.15.1 (Bluetooth). When these standards are not applicable system specific solutions or alternative radio link equipment (e.g. satellite communication) can be used. Main challenges off data transmission part are performance, low overhead and network integrity achieved simultaneously with limited resources of platforms.

Power supply in most cases is represented as small energy element with one charge cycle. Possibility of battery recharging or change in most cases is not achievable due to high number of nodes and their spatial distribution. Special technics such as duty cycles and power saving modes can be used for node lifetime extension.

Satellite technologies application in WSN scope in general can be divided into two groups. First one uses satellite link as a backhaul (or backbone) facility and adopts high performance standards with VSAT equipment and wideband signal and low latency network access. This use case is described in the following section. Another possibility is to use satellite radio link for immediate data transfer from sensor nodes. It requires usage of L-band frequencies and lower and applicable for low intensity traffic (random medium access or sensor node polling).

\section{Satellite link usage between gateway node and datacenter}

Most frequent method of STS application in WSN is data transmission from gateway sensor node to datacenter. Fig.2a shows such architecture [2]. Satellite channel doesn't take part in data transmission among sensor nodes. Satellite is used as connection section between sensors deploying territory and point, where high speed terrestrial communications exist. In work [4] it is in details described successful design of WSN network for data collection during ecological researches.

Such approach in WSN design can be effective in situations, when terrestrial communications (both cable and wireless):

- don't exist on sensor network deployment territory;

- can't be used due to administrative or other reasons;

- don't guaranty required throughput, service quality or robustness;

- are not acceptable due to security reasons; 
- can be affected or totally destroyed during natural or industrial disasters.

In general case, satellite communication channel should be considered as a primary solution, when territory of sensor location and its state can't be defined on system design stage, but characteristics of future system surrounding infrastructure vary dramatically. Satellite technologies can guaranty lowest time of WSN launch, if it is possible to ship satellite terminal in target area. Fig. $2 \mathrm{~b}$ illustrates possible construction of satellite terminal for gateway sensor node.

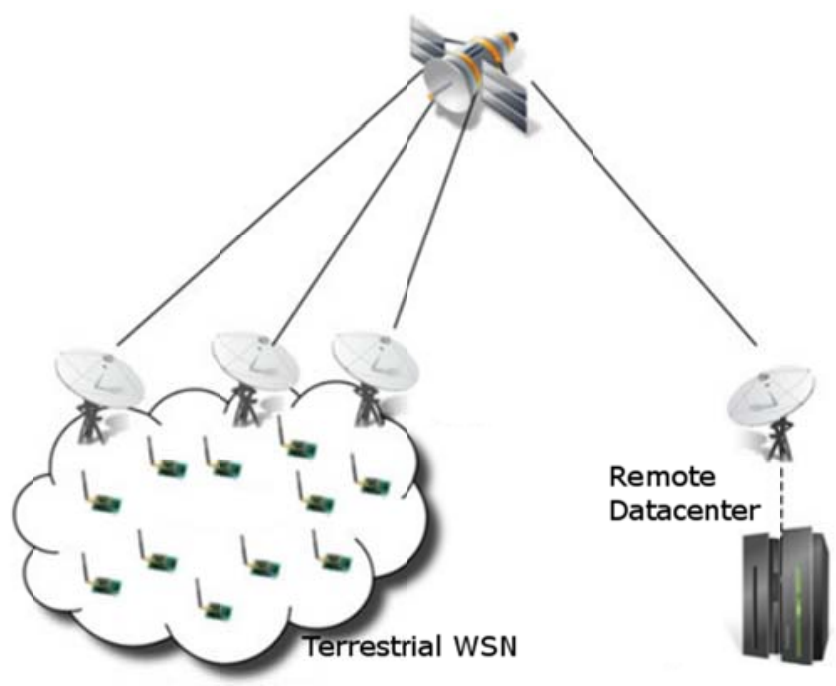

(a)

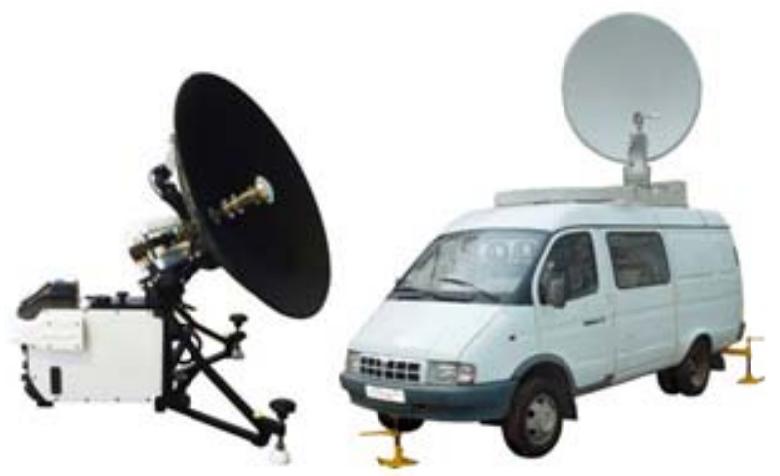

(b)

Fig. 2. WSN with satellite link between gateway node and data center (a); possible construction of satellite terminal for gateway node (b)

Such terminals respectively can have fixed location or be mounted on moveable platform for different applications.

Depends on system properties (such as satellite channel load pattern), efficient technologies of satellite segment can vary drastically. If we have requirements of real time data transfer with defined rate and low latency, dedicated fixed rate will be simple and efficient solution. When channel utilization and terminal power consumption have larger priority than low latency, satellite systems with periodical station polling can be used. For WSNs without continuous data transmission (e.g. sensor detects threshold crossing of measuring parameter and triggers data transmission), which generate low amount of data with long silent terms, most efficient can be channel with random access.

Another example with similar architecture is shown in [5] where satellite link is used for connection body sensor network (BSN) to telemedicine center. Such solution allows providing continuous health monitoring of ill patients without ground communication dependencies.

In [6] Ku- or Ka-band satellite links are considered for data transmission on top level of nodes hierarchy in environment monitoring systems with high traffic generation (image sensors and/or smart cameras).

\section{Sensors with satellite interface}

In some cases it is possible to consider group of radio nodes, which do not communicate each other with any wireless technology. Satellite link is only one possibility of signal transmission for nodes. Example of such system is search and rescue services. They are best known as the systems that detect and locate emergency beacons activated by aircraft, ships and backcountry hikers in disasters [7]. Personal radio signal transmitter can be considered as node in highly distributed sparse sensor networks.

In most of such systemis Low Earth Orbit (LEO) satellites are used. They can scan whole Earth surface even without simultaneous global coverage and detect emergency signal in limited time period. LEO satellites and narrow signal band allow keeping personal beacons compact and energy efficient.

Energy and dimension limitations of sensor nodes restrict possibility to transfer high speed traffic (video, high resolution pictures) directly via satellite. Example of satellite incorporation in such systems is represented in [8] where satellites are used for backbone construction in hybrid sensor network. Sensor nodes only inform system about emergency situation when satellite requests information updates. After emergency message received uninhabited aerial vehicles (UAVs) are launched for territory investigation and pictures capturing. These UAVs with higher energy resources can use the same satellite for multimedia data transfer to central station.

Energy limits restrict throughput of physical layer which causes higher requirements of low overhead in medium access control protocol. Multiple access issues are faced in work [9], which results propose estimation 
of tradeoff between throughput and latency for satelliterouted disaster detection WSN.

\section{Collaborative beamforming in WSN}

Beamforming is a technique that is used for directional signal transmission or reception and it relies on the artificial creation of multipath fading by equipping the transmitter with multiple antennas and by sending the same signal from each antenna. Nevertheless, battery-limited devices in WSNs are likely to be equipped with a single antenna and so they cannot use beamforming. A solution to this is to let nearby nodes to cooperate with each other by sharing their transmission data and then synchronously transmit the compound data to the destination. In essence, a set of distributed wireless nodes organizes itself as a virtual antenna array and produces a desired beam pattern. Such a beamforming is referred to as collaborative beamforming (CB).

In work [10] it is proposed to use $\mathrm{CB}$ for data transmission between two remote groups of sensor nodes. Hybrid MESH-network structure can be achieved in such way. In other works [2] $\mathrm{CB}$ is described for satellite or high altitude platform channels establishing (Fig.3).

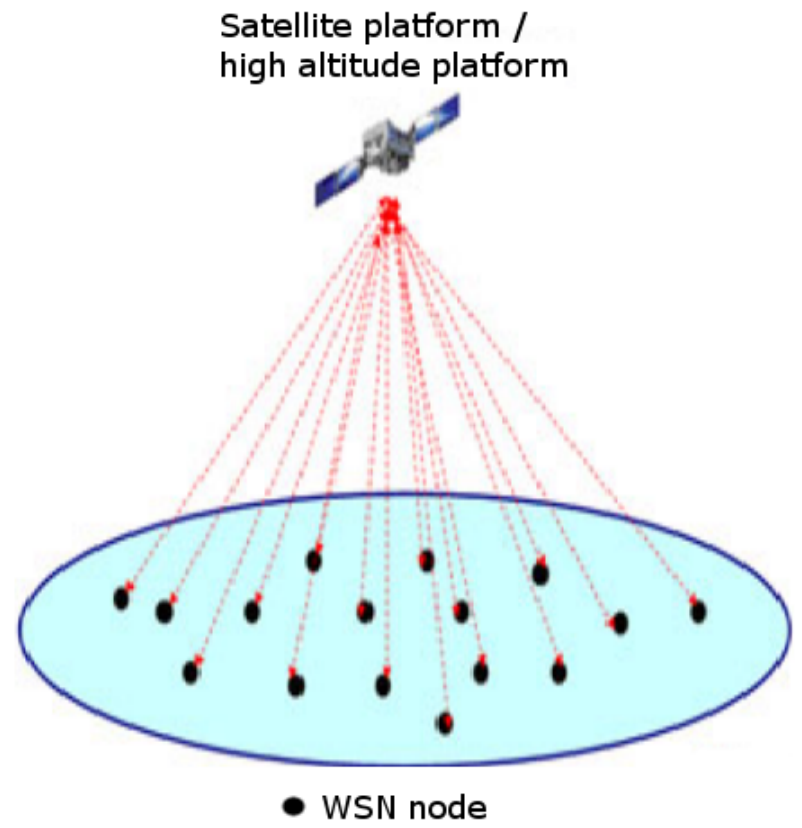

Fig. 3. Collaborative beamforming for low power nodes [2]

CB may be adopted in modern WSNs for different purposes such as to minimize the networks' black-out spots by balancing the node's transmission energy as well as to improve data security by eliminating signals to undesired directions.

$\mathrm{CB}$ can be achieved by properly manipulating the initial phase of the transmitted signal of each node which are phase synchronized and have identical messages. Two possible scenarios can be used: closedloop and open-loop scenario. In the first one, each node independently synchronizes itself to a beacon sent from the destination adjusting its initial phase, while in the second one, all nodes within a group acquire their relative locations from a beacon of a nearby reference point (master node or cluster head).

\section{Satellite sensor networks}

Traditional satellite missions are extremely expensive to design, build, launch and operate. Because of the high cost, the aerospace industry have started directing its attention to missions consisting of many, distributed, small and inexpensive satellites. Distributed space missions consist of multiple satellites working in a coordinated fashion to execute the mission's common goal. Earth Observation (EO) is one of the main focuses of both the industry and the research community. EO missions consist of a group of nano-satellites, small satellites with a mass of a few kilograms, or picosatellites, with a mass of less than one kilogram, flying in formation or forming a constellation [11].

Applying of small satellite platforms as sensor network nodes is not very common example of WSN, but such design follows definition of these systems. Satellite sensor nodes can perform measurements of environment in space orbit (e.g. electromagnetic radiation) or on Earth surface (with optical device). It is not necessary for each satellite to establish direct transmission link to Earth stations. In such systems intersatellite links are frequently used, which can be organized in radio or optical band [12].

Research work [13] presents possibility to apply commonly used communication technologies and standards of terrestrial WSN for intersatellite communication (with link range up to $15 \mathrm{~km}$ ). IEEE 802.15.4 ZigBee communication channel was implemented in nano-satellite project. This example proves concept of low-cost radio equipment usage for communication of high density low-orbit satellite groups.

\section{WSN nodes localization}

The importance of localization information arises from several factors, many of which are related only to WSNs. These factors include the identification and correlation of gathered data, node addressing, management and query of nodes localized in a determined region, evaluation of nodes' density and coverage, energy map generation, geographic routing, object tracking, and other geographic algorithms. 
Unfortunately, for a large number of sensor nodes, straightforward solution of adding GPS to all nodes in the network is not always feasible.

There are a lot of methods for sensors localization which use different physical phenomena to compute relative positions among WSN nodes. [14]. However, for terrain binding some sensor nodes may be equipped with GPS receiver to act as beacons for other nodes to infer their location [15].

In general, satellite-based positioning systems such as GPS or GLONASS provide capabilities for precise nodes localization, but a lot of WSN equipment limitations require hybrid schemas of node localization.

\section{Energy aspects}

As was mentioned few times above, WSN nodes in most cases have restrictions of power supply capacity. This fact requires energy efficiency optimizations of all nodes' subsystems. One of the main sources of energy consumption in sensor nodes is communication function which includes listening to the wireless channel and transceiving packets.

For WSN nodes equipped with satellite or UAV links energy consumption of communication subsystem can be significantly (orders of magnitude) larger. In most cases described in previous chapters (except satellite link as a bridge between sink and datacenter) power efficiency becomes primary issue.

In state of the art WSN systems power saving measures are applied on different levels implicitly or explicitly.

Optimizations of nodes interaction on application level are implemented with different data aggregation technics [16]. Amount of data samples transferred from sensors can be reduced both in time dimension (only average/maximum value in measurement period is sent) and spatial dimension (aggregate nodes combine data from subordinate sensor nodes). In any case the goal of data aggregation is to reduce amount of transmitted information via wireless link. However, data processing on aggregation stage causes additional power consumption by processor unit. This fact requires tradeoff solution. In context of satellite communication links (high power cost of data transfer) data aggregation is more efficient than for typical WSN.

For sensor nodes with satellite link network routing problem is trivial: nodes either are connected to one GEO satellite or to one of LEOs which is determined by schedule. Nevertheless medium access problem has additional issues in consequence of link delay and impossibility for nodes to listen common satellite channel. Terrestrial WSNs use power saving technics of MAC layer such as node duty cycles, deterministic medium access protocols (signal transmission by schedule), etc. [17] which can be effectively reused for satellite connection of separate nodes.

Another approach for WSN node lifetime extension is energy harvesting [17]. This technic introduces converting ambient energy to electrical energy which can be used for node supply. This approach is not commonly adopted in WSN nodes design because of small size and low cost requirements of such devices. However for specific sensor networks with more complex nodes (large number of sensors) which can be equipped with satellite communication module additional energy harvesting subsystem (e. g. solar panels) can provide efficient solution of power problem without extreme node price increase compared to initial hardware cost.

The last large group of energy efficiency improvements we consider for satellite linked WSN nodes is physical layer upgrade. Except different straightforward technics such as increased power supply capacity or energy efficient power amplifier more sophisticated solutions exist. Sensor network paradigm adopts use of low-directional (in many assumptions omni-directional) antennas. Application of directional ("smart") antennas for WSN nodes is a current research area which goal is to extend communication capabilities of nodes without power overconsumption or energy saving with constant transmission range. Application of antenna system with controlled narrow beam provides possibility of satellite connection for cases where transmitter power is too low.

\section{Conclusions}

Survey demonstrates example of systems and services, where satellite technologies are adopted as effective solution for WSN communication problems. Despite of additional complexities in satellite channels caused by sensor node signal power requirements, satellite systems can provide desirable territorial deployment flexibility for WSN.

Traditional use of satellite technologies as connecting chain between terrestrial WSN and datacenter still has open topics for research. One example is problem of multiple access organization in satellite channel for high satellite channel utilization depends on payload traffic nature.

Some modern ideas as collaborative beamforming have not been widely adopted in production systems yet. But it can be considered as a perspective for WSN technologies evolving.

Additional energy consumption which can appear with satellite communication is taken into a count, so 
we propose short survey of power saving technics suitable for WSN networks.

\section{References}

1. Baskakov S., Oganov V. Besprovodnye sensornye seti na baze platformy MeshLogic // "Elektronnye komponenty", №8, 2006.

2. Celandroni N., Ferro E., Gotta A. A survey of architectures and scenarios in satellite-based wireless sensor networks: system design aspects. // Int. J. Satell. Commun. Network., 31: 1-38. doi: 10.1002/sat.1019

3. Dargie, Waltenegus, and Christian Poellabauer. Fundamentals of wireless sensor networks: theory and practice. John Wiley \& Sons, 2010.

4. Ye, Wei, et al. "Architecture of a Satellite-Based Sensor Network for Environmental Observation." Proc. of the Earth Science Technology Conference (ESTC). 2008.

5. Rahim Kacimi, Ponia Pech "Hybrid Satellite - Wireless Sensor Networks Architecture for Telemedicine Applications in the Context of Emergency Satellite Communications in $\mathrm{Ku} / \mathrm{Ka} / \mathrm{Q} / \mathrm{V}$ Bands", MCA, ICST. 2014.

6. Munir, Arslan, Ann Gordon-Ross, and Sanjay Ranka. "Multi-core embedded wireless sensor networks: Architecture and applications." Parallel and Distributed Systems, IEEE Transactions on 25.6 (2014): 1553-1562.

7. Lewandowski A., Niehoefer B., Wietfeld C. Performance Evaluation of Satellite-Based Search and Rescue Services: Galileo vs. Cospas-Sarsat // Vehicular Technology Conference, 2008. VTC 2008-Fall. IEEE 68th, vol., no., pp.1,5, 21-24 Sept. 2008

8. Hamdi Mohamed, Noureddine Boudriga, and Mohammad S. Obaidat. "Bandwidth-effective design of a satellite-based hybrid wireless sensor network for mobile target detection and tracking." Systems Journal, IEEE 2.1 (2008): 74-82.
9. Kawamoto, Y., Nishiyama, H., Kato, N., Yamamoto, S., Yoshimura, N., \& Kadowaki, N. On real-time data gathering in next generation satellite-routed sensor system (SRSS). In Wireless Communications \& Signal Processing (WCSP), 2012 International Conference on (pp. 1-5). IEEE.

10. Ochiai H., Mitran P., Poor H., Tarokh V. Collaborative beamforming for distributed wireless ad hoc sensor networks // Signal Processing, IEEE Transactions on, vol.53, no.11, pp.4110,4124, Nov. 2005

11. Walter Colitti, Kris Steenhaut, Nicolas Descouvemont, and Adam Dunkels. 2008. Satellite based wireless sensor networks: global scale sensing with nano- and pico-satellites. In Proceedings of the 6th ACM conference on Embedded network sensor systems (SenSys '08).

12. G. Maral, M. Bousquet, Satellite Communication Systems. Systems, Techniques and Technology. Fifth Edition. Wiley 2009

13. Xie, Shuanglong, et al. "Wireless Sensor Network for Satellite Applications: A Survey and Case Study." Unmanned Systems 2.03 (2014): 261-277.

14. Sichitiu, M. L., \& Ramadurai, V. (2004, October). Localization of wireless sensor networks with a mobile beacon. In Mobile Ad-hoc and Sensor Systems, 2004 IEEE International Conference on (pp. 174-183). IEEE.

15. Römer, K., \& Mattern, F. (2004). The design space of wireless sensor networks. Wireless Communications, IEEE, 11(6), 54-61.

16. Tossaporn Srisooksai, Kamol Keamarungsi, Poonlap Lamsrichan, Kiyomichi Araki, "Practical data compression in wireless sensor networks: A survey", Journal of Network and Computer Applications, Volume 35, Issue 1, January 2012, Pages 37-59.

17. Iannello, F.; Simeone, O.; Spagnolini, U., "Medium Access Control Protocols for Wireless Sensor Networks with Energy Harvesting," Communications, IEEE Transactions on, vol.60, no.5, pp.1381,1389, May 2012.

Received in final form on April 25, 2016 


\section{О.І. Лисенко, С.В. Кашуба, В.І. Новіков, Т.О. Прищепа.}

\section{Огляд застосування супутникових технологій в безпроводових сенсорних мережах}

Проблематика. Існують сценарії застосування безпроводових сенсорних мереж, в яких використання наземного зв'язку стає неприйнятним: значна відстань між сенсорними вузлами, руйнування наземних ліній зв'язку під час стихійних лих та ін. Альтернативою наземного зв'язку при вирішенні завдання забезпечення передачі інформації від сенсорних вузлів може бути використання супутникових каналів зв'язку. Однак використання супутникового каналу пред'являє високі вимоги до енергетики приймально-передавальних пристроїв, що накладає обмеження на характеристики сенсорних вузлів.

Мета досліджень. Огляд існуючих методів застосування супутникових каналів зв'язку в безпроводових сенсорних мережах.

Методика реалізації. Аналіз відомих публікацій, присвячених застосуванню супутникових каналів зв'язку в безпроводових сенсорних мережах, дозволив виявити характерні сценарії, в яких застосування супутникових каналів може бути ефективним рішенням.

Результати досліджень. Встановлено, що, незважаючи на додаткові складності застосування супутникових каналів зв'язку в безпроводових сенсорних мережах, які пов'язані з енергетичними обмеженнями сенсорних вузлів, супутникові канали здатні забезпечити необхідну територіальну гнучкість при розгортанні безпроводових сенсорних мереж.

Висновки. Використання супутникових каналів зв'язку в безпроводових сенсорних мережах має ряд невирішених проблем. Наприклад, відсутня методика вибору протоколу множинного доступу до супутникового каналу, яка необхідна для ефективного використання ресурсів каналу при передачі різних типів трафіка. Перспективним напрямком застосування супутникових каналів зв'язку в безпроводових сенсорних мережах є метод утворення каналу передачі даних від групи рознесених сенсорних вузлів з енергетичними обмеженнями, який базується на принципах фазованих антенних решіток.

Ключові слова: безпроводові сенсорні мережі, супутниковий канал.

\section{А.И. Лысенко, С.В. Кашуба, В.И. Новиков, Т.А. Прищепа.}

\section{Обзор применения спутниковых технологий в беспроводных сенсорных сетях}

Проблематика. Существуют сценарии применения беспроводных сенсорных сетей, в которых использование наземной связи становится неприемлемым: значительное расстояние между сенсорными узлами, разрушение наземных линий связи во время стихийных бедствий и др. Альтернативой наземной связи при решении задачи обеспечения передачи информации от сенсорных узлов может быть использование спутниковых каналов связи. Однако использование спутникового канала предъявляет высокие требования к энергетике приемо-передающих устройств, что накладывает ограничения на характеристики сенсорных узлов.

Цель исследований. Обзор существующих методов применения спутниковых каналов связи в беспроводных сенсорных сетях.

Методика реализации. Анализ известных публикаций, посвященных применению спутниковых каналов связи в беспроводных сенсорных сетях, позволил выявить характерные сценарии, в которых применение спутниковых каналов может быть эффективным решением.

Результаты исследований. Установлено, что, несмотря на дополнительные сложности применения спутниковых каналов связи в беспроводных сенсорных сетях, связанные с энергетическими ограничениями сенсорных узлов, спутниковые каналы способны обеспечить необходимую территориальную гибкость при развертывании беспроводных сенсорных сетей.

Выводы. Использование спутниковых каналов связи в беспроводных сенсорных сетях имеет ряд не решенных проблем. Например, отсутствует методика выбора протокола множественного доступа к спутниковому каналу, необходимая для эффективного использования ресурсов канала при передаче различных типов трафика. Перспективным направлением применения спутниковых каналов связи в беспроводных сенсорных сетях является метод образования канала передачи данных от группы разнесенных сенсорных узлов с энергетическими ограничениями, который базируется на принципах фазированных антенных решеток.

Ключевые слова: беспроводные сенсорные сети, спутниковый канал. 